\title{
Analisis Marketing Mix DBL Academy
}

\author{
Edwin Putra Surya Prasetyo
}

Mahasiswa Pasca Sarjana Universitas Katolik Widya Mandala Surabaya, Indonesia

Email: edwinpsp.11@gmail.com

\section{Artikel info \\ Artikel history:}

Diterima : 15-05-2021

Direvisi : 10-06-2021

Disetujui : 15-06-2021

Keywords:

marketing mix; DBL academy; brand awareness.

Kata kunci:

bauran pemasaran; DBL; academy; brand awareness

\begin{abstract}
:
Sport is one of the development of human interests and talents that can be honed from an early age. One of the most popular sports in Indonesia is basketball. Basketball is quite popular but it is rare for the development of interest and talent in this sport to be monitored early on. DBL Academy is a means of channeling and gaining knowledge and self-development from its participants from an early age. DBL Academy's marketing method is a challenge because it targets middle to upper class participants, so it requires a special marketing method to attract attention, especially from prospective DBL Academy students. In this study, it can be seen that DBL Academy has implemented the marketing mix well. From the seven marketing concepts that have been built by DBL Academy, it can be concluded that DBL Academy adopts a word of mouth marketing communication strategy, so that in the future it can use social media to get more optimal results.
\end{abstract}

\begin{abstract}
Abstrak:
Olahraga merupakan salah satu pengembangan minat dan bakat manusia yang dapat diasah sejak dini. Salah satu olahraga yang digemari oleh masyarakat Indonesia adalah bola basket. Bola basket cukup populer namun jarang sekali perkembangan minat dan bakat pada olahraga ini terpantau sejak dini. DBL Academy merupakan sarana menyalurkan dan menimba ilmu serta pengembangan diri dari para pesertanya sejak dini. Metode pemasaran DBL Academy menjadi tantangan karena menyasar peserta kelas menengah ke atas sehingga memerlukan metode pemasaran khusus untuk menarik perhatian terutama dari calon mahasiswa DBL Academy. Dalam penelitian ini dapat diketahui bahwa DBL Academy telah menerapkan marketing mix dengan baik. Dari tujuh konsep marketing yang telah dibangun oleh DBL Academy dapat disimpulkan bahwa DBL Academy mengambil strategi komunikasi pemasaran dari mulut ke mulut, sehingga untuk kedepannya dapat menggunakan media sosial agar mendapatkan hasil yang lebih optimal.
\end{abstract}

Coresponden author: Edwin Putra Surya Prasetyo Email: edwinpsp.11@gmail.com artikel dengan akses terbuka dibawah lisensi CC BY SA 2021

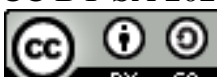

\section{Pendahuluan}

Olahraga merupakan kegiatan yang bertujuan untuk mengasah jasmani dan rohani dari manusia. Olahraga juga menjadi hal penting untuk menjaga kebugaran tubuh, oleh karena gerakan-gerakan yang membantu melatih otot dan kekuatan tulang. Olahraga juga dapat 
menjadi sarana untuk mengembangkan minat dan bakat sekaligus pelaku olahraga berkesempatan berprestasi dalam berbagai macam perlombaan yang diselenggarakan oleh swasta maupun pemerintah.

Di Indonesia, ada berbagai macam jenis olahraga yang populer. Bola basket adalah salah satu olahraga yang bisa dikatakan populer selain bulu tangkis atau sepak bola yang juga menjadi favorit olahraga di Indonesia. Olah raga basket sering dianggap menjadi olahraga yang eksklusif karena peralatan yang digunakan seperti bola dan sepatu yang tergolong memiliki harga mahal seringkali ditinggalkan oleh masyarakat Indonesia yang cenderung memilih olahraga simpel lain seperti sepak bola yang tidak memerlukan peralatan yang terlalu mahal. Basket yang merupakan olahraga beregu memiliki keunggulan dalam pembentukan mental pemainnya karena terkandung nilai-nilai seperti kebersamaan, kekompakan, kejujuran, menerima kelebihan lawan atau tim-tim lain yang merupakan salah satu cara untuk mewujudkan pribadi yang unggul. Pertandingan bolabasket di Indonesia saat ini sedang berkembang pesat terbukti dengan diadakannya berbagai kejuaraan yang mendukung perkembangan talenta muda di Indonesia.

DBL Indonesia adalah salah satu perusahaan swasta penyelenggara kegiatan bola basket yang ada di Indonesia mulai dari kompetisi hingga pembinaan pemain muda. Perusahaan tersebut memiliki beberapa unit bisnis seperti DBL dan JrBL yang merupakan event perlombaan basket yang diselenggarakan untuk anak SMA dan SMP. Berikutnya ada DBL Store yang merupakan cabang DBL Indonesia yang bergerak pada industri retail dengan menjual berbagai perlengkapan olahraga terutama basket. Selain itu DBL memiliki jaringan publikasi berupa majalah dengan nama Mainbasket yang memberikan informasi mengenai fundamental basket, maupun perkembangan basket di Indonesia dan juga internasional. DBL juga memiliki DBL Academy untuk membentuk fundamental basket dengan berbagai pelatihan untuk anak usia dini hingga jenjang SMP.

DBL Academy adalah sekolah basket yang dikembangkan oleh DBL Indonesia dan tergolong masing muda, umur nya masih 4 tahun sehingga masih butuh pengembangan terkait pola pemasarannya. Usia DBL Academy yang tergolong masih baru, DBL Academy fokus untuk mengembangkan pemasaranya untuk membangun brand awareness dari DBL Academy. Tujuan dari penelitian ini adalah untuk mengetahui strategi marketing mix yang dilakukan oleh DBL Academy untuk menumbuhkan kesadaran orang tua murid akan pentingnya pengembangan bakat anak mulai sejak dini khususnya dibidang olahraga basket.

\section{Tinjauan Pustaka}

\section{DBL Indonesia}

PT. Deteksi Basket Lintas (DBL) Indonesia berdiri sejak tahun 2008. PT. DBL Indonesia sendiri merupakan anak perusahaan dari Jawa Pos Grup yang bernaung di Surabaya. Tujuan dari berdirinya PT. DBL Indonesia adalah untuk mengelola kompetisi liga basket tingkat pelajar SMA terbesar di Indonesia, yaitu Developmental Basketball League (DBL). Pada awal pembentukannya, PT. DBL Indonesia hanya memiliki lima orang staf saja. Pada awalnya DBL hanyalah kompetisi poster antar sekolah di Surabaya yang kemudian berkembang menjadi bisnis yang sukses dengan berbagai kompesitisi untuk siswa SMP dan SMA. 
Untuk sekarang sekitar 170 staf telah bekerja pada satu - satunya perusahaan yang bergerak dibidang sport event tersebut. Logo DBL terbaru saat ini dapat dilihat pada Gambar 1.

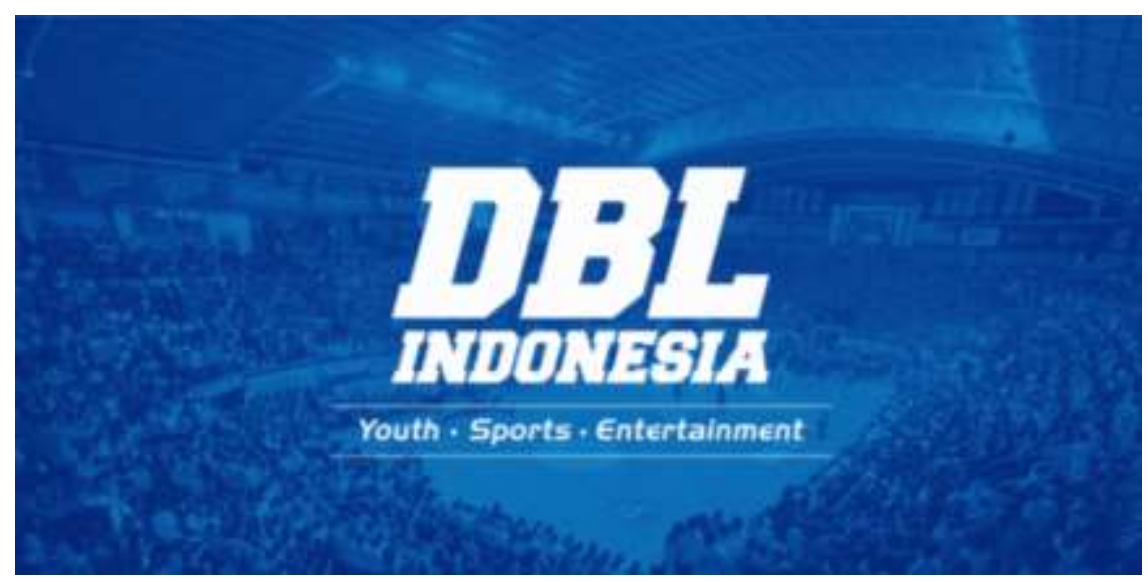

Gambar 1. Logo DBL Indonesia

Saat PT. DBL Indonesia tidak hanya mengelola liga DBL saja, namun juga menaungi liga utama lainnya, seperti liga basket bagi pelajar tingkat SMP di Indonesia, yaitu Junior Basketball League (JRBL) dan DBL Academy untuk membentuk potensi dari talenta muda Indonesia. Selain itu, DBL juga menyelenggarakan seleksi tim DBL yang akan diberangkatkan ke Amerika untuk 12 pemain terpilih dari berbagai daerah di Indonesia yang diberi nama DBL All Star.

\section{DBL Academy}

DBL Academy berawal pada tanggal 25 Januari 2016. Sekolah olahraga ini bertujuan untuk menumbuhkan ketertarikan anak dan orang tua untuk mengembangkan pribadi anak dengan media olahraga basket. Visi dari DBL Academy didukung dengan fasilitas unggulan dengan standar internasional yang dimiliki oleh DBL Academy, bahkan pelatih atau coach yang dimiliki merupakan pemain basket professional yang memiliki riwayat kejuaraan olahraga dalam bidang basket. Hingga saat ini, DBL Academy menjalankan dua program yang sedang berjalan, yaitu Regular Program dan Special Program. Reguler Program DBL Academy berisi mengenai pelatihan basket sederhana dan juga coaching clinic untuk mereka yang awam terhadap olahraga basket. Logo DBL Academy dapat dilihat pada Gambar 2.

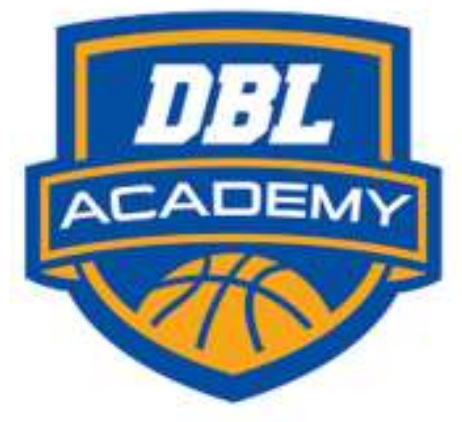

\section{Gambar 2. Logo DBL Academy}

Special program memiliki agenda khusus seperti latihan menembak bola dan latihan khusus untuk meningkatkan skill pemain. DBL Academy juga memiliki program basketball clinic yang pelaksanaannya menyasar anak usia 7-15 tahun yang merupakan usia yang ideal 
untuk menumbuhkan skill basket. Program lain yang dilakukan oleh DBL Academy adalah road show, road show ini dilakukan dengan latar belakang untuk mengenalkan kepada siswa mengenai keunggulan dari DBL Academy yang kemudian harapannya mereka sharing kepada orang tuanya untuk didaftarkan di DBL Academy. Road show ini biasa dilakukan di sekolah-sekolah yang masuk kartegori sekolah dengan kemampuan finansial menengah keatas sesuai dengan target pasar dari DBL Academy sendiri. Salah satu poin penting pelaksanaan road show ini adalah kesempatan yang diberikan kepada calon siswa yang berminat untuk melakukan trial pelatihan DBL Academy, dengan mendapatkan pengalaman ini diharapkan anak tersebut dapat mendapatkan pengalaman mengesankan dan berminat untuk melanjutkan pelatihan secara berbayar. Pihak dari DBL Academy meminta bantuan dari pihak sekolah untuk mengirimkan beberapa siswa yang berminat atau berbakat untuk mencoba keseruan dan ilmu yang ditawarkan oleh DBL Academy.

Menurut Agus (2012) pada dasarnya pemasaran adalah kegiatan yang dilakukan untuk mempromosikan barang atau jasa yang akan dijual kepada publik maka dari itu publik harus menerima pengalaman untuk mencoba terlebih dahulu. Namun, dalam proses pemasaran, perusahaan harus memiliki stratergi khusus untuk menawarkan barang maupun jasanya (Agus, 2012). Strategi pemasaran penting bagi semua perusahaan, dengan adanya strategi pemasaran diharapkan dapat meningkatkan potensi omzet dari perusahaan. Bahkan, menurut Agus (2012), tanpa strategi pemasaran yang teruji maka pemasaran akan jatuh. Berkaitan dengan pengertian diatas, pemasaran sendiri juga memiliki tiga tujuan yaitu :

1. Calon konsumen memahami produk yang ditawarkan oleh perusahaan.

2. Perusahaan dapat menjelaskan dengan detail kepada calon konsumen mengenai produk yang ditawarkan:

3. Perusahaan harus mampu membentuk proses bisnis yang ideal mulai dari produksi, pemasaran hingga distribusi ke konsumen.

\section{Strategi Pemasaran}

Menurut (P. Kotler \& Keller, 2005) menyatakan bahwa perusahaan tahu bahwa mereka tidak dapat menguntungkan semua pelanggan di pasar tertentu, setidaknya tidak semua pengguna dengan cara yang sama. Ada terlalu banyak jenis pengguna dengan terlalu banyak jenis kebutuhan. Sebagian besar perusahaan berada dalam posisi untuk memberikan beberapa segmen yang lebih baik daripada yang lain. Oleh karena itu, setiap perusahaan harus membagi jumlah pasar, memilih segmen terbaik dan merancang strategi untuk menguntungkan segmen yang dipilih. Proses ini melibatkan segmentasi pasar, penargetan pasar, diferensiasi dan posisi.

\section{Segmenting}

Pasar terdiri dari berbagai jenis pengguna, produk, dan kebutuhan. Perusahaan harus menentukan segmen untuk menentukan target pemasaran dari produk mereka. Target ini dapat memperhatikan berdasarkan faktor geografis, demografis, psikografis dan perilaku (Gould, 2012). Proses membagi pasar menjadi kelompok pembeli yang berbeda dengan kebutuhan, fitur, atau perilaku yang berbeda dan yang mungkin memerlukan strategi atau campuran pemasaran yang terpisah (P. Kotler \& Keller, 2009) 
Segmen pasar biasanya diidentifikasi dalam beberapa bagian seperti pola belanja, lokasi geografis, pola pengeluaran, sensitifitas marketing mix, dan sebagainya, serta cara berkomunikasi baik itu secara demografis, psikologis, mupun melalui media (P. and G. A.

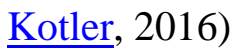

\section{Targeting}

Setelah melakukan analisis segmentasi, tahapan selanjutnya menetapkan target pasar atau targeting guna memilih satu atau beberapa segmen untuk dilayani. Untuk itu diperlukan suatu analisis daya tarik segmen dan kekuatan bisnis untuk pemanfaatan suatu peluang yang ada. Analisis target pasar adalah kegiatan untuk melakukan evaluasi daya tarik masingmasing segmen dan kemudian memilih segmen-segmen sasaran yang dituju (P. and G. A.

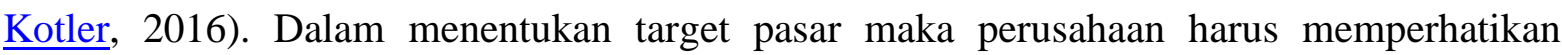
segmen mana yang akan dimasuki oleh produk yang ditawarkan oleh perusahaan.

\section{Positioning}

Positioning merupakan langkah selanjutnya setelah menetapkan sasaran pasar yang diilih oleh perusahaan. Tujuan positioning adalah untuk menanamkan persepsi ke dalam benak konsumen akan posisi suatu produk (Adiana, 2014). Positioning merupakan suatu strategi pemasaran yang menitikberatkan pada komunikasi perusahaan untuk menyampaikan suatu keunggulan dan nilai lainnya atas produk yang ditawarkan melalui suatu keunikan agar dapat lebih mudah diingat dan diterima oleh konsumen (P. Kotler \& Keller, 2009).

\section{Marketing Mix}

Dasar-dasar pemasaran dikenal sebagai 4P yang berarti Produk, Harga, Tempat, dan Promosi. Namun, ketika pelanggan menjadi lebih intens, ada penambahan 3P untuk layanan industri yaitu Orang, Proses, dan Lingkungan fisik. Saat ini 7 model tersebut dikenal sebagai pemasaran 7P dan kadang disebut dengan marketing mix.

Marketing mix menurut (P. Kotler \& Keller, 2005) adalah seperangkat alat pemasaran taktis yang dipadukan perusahaan untuk mengahasilkan respon yang diinginkan di pasar sasaran. Marketing mix terdiri dari segala hal yang dapat dilakukan perusahaan untuk melibatkan konsumen dan memberikan nilai pelanggan. Menurut (Cristea, 2014) Marketing mix dikenal dengan sebutan 7P yaitu Product, Price, Place, Promotion, People, Physical evidence dadn Process. Adapun pengertian 7P :

\section{Produk (Product)}

Produk adalah kombinasi barang atau jasa perusahaan yang ditawarkan ke target pasar untuk dapat memuhi keinginan atau kebutuhan konsumen. Sebagian besar pendapatan suatu perusahaan berasal dari produk yang dijualnya kepada konsumen, konsumen akan membeli produk tersebut untuk keperluannya sehari-hari, maupun untuk memenuhi kepuasannya sehingga perusahaan harus melakukan pengembangan produk atau jasa untuk dipasarkan (Hisrich, 2015).

2. Harga (Price)

Harga merupakan marketing mix yang bersifat fleksibel dimana suatu harga akan stabil dalam jangka waktu tertentu tetapi, dalam seketika harga dapat meningkat atau menurun 
yang terdapat pada pendapatan dari hasil penjualan. Selain itu harga juga merupakan jumlah uang yang nantinya dijadikan sebagai alat tukar barang atau jasa (ㅁaet, 2007).

\section{Tempat (Place)}

Tempat atau lokasi yang strategis akan menjadi salah satu keuntungan bagi perusahaan karena mudah dijangkau oleh konsummen, namun sekaligus menjadikan biaya rental atau investasi tempat menadi semakin mahal. Tingginya biaya lokasi tersebut dapat terkompensasi dengan reducing biaya marketing lebih mahal untuk menarik konsumen agar berkunjung.

\section{Promosi (Promotion)}

Promosi merupakan suatu aktivitas dan materi dalam aplikasinya menggunakan teknik, bahwa pengendalian penjualan yang dalam mengkomunikasikan informasi persuasif yang menarik tentang produk yang ditawarkan oleh penjual, baik secara langsung maupun pihak yang dapar mempengaruhi pembelian (Korkmaz \& Messner, 2008).

5. Orang (People)

Orang merupakan aset utama dalam industri terutama jasa, terlebih apabila people tersebut adalah karyawan dengan performance tinggi. Kebutuhan konsumen terhadap karyawan berkinerja tinggi akan menyebabkan konsumen puas dan loyal. Kemampuan knowledge (pengetahuan) yang baik, akan menjadi kompetensi dasar dalam internal perusahaan dan pencitraan yang baik diluar. Faktor penting lainnya dalam people adalah attitude dan motivasi dari karyawan. Moment of truth akan terjadi pada saat terjadi kontak antara karyawan dan konsumen. Attitude sangat penting, dapat diaplikasikan dalam berbagai bentuk seperti penampilan karyawan, suara dalam berbicara, body language, ekspresi wajah, dan tutur kata. Sedangkan motivasi karyawan diperlukan untuk mewujudkan penyampaian pesan dan jasa yang ditawarkan pada level yang dieskpetasikan.

6. Fasilitas fisik (Physical Evidence)

Sarana fisik merupakan hal nyata yang turut mempengaruhi keputusan konsumen untuk membeli dan menggunakan produk atau jasa yang ditawarkan. Untuk yang termasuk dalam sarana fisik antara lain lingkungan atau bangunan fisik, peralatan, perlengkapan, logo, warna, dan barang-barang lainnya.

\section{Proses (Process)}

Proses adalah dimana pelayanan menjadi perhatian, penciptaan dan pemberian elemen produk memelurkan desain dan pelaksanaan proses yang efektif. Selain itu proses merupakan semua prosedur aktual, mekanisme, dan aliran aktivitas yang digunakan untuk menyampaikan jasa. Elemen proses ini memiliki arti sesuatu untuk menyampaikan jasa. Proses dalam jasa akan senang merasakan sistem penyerahan jasa sebagai bagian jasa itu sendiri (Anthony E. Henry, 2011).

\section{Brand Awareness/Brand Equity}

Brand Awareness menggambarkan keberadaan brand dalam benak konsumen, yang dapat menjadi penentu dalam beberapa kategori (Durianto, 2004). Membangun dan menumbuhkan brand awareness atau kesadaran merek merupakan suatu hal yang mutlak diperlukan untuk keberlangsungan suatu produk. Brand Awareness berperan dalam proses pengenalan melalui penyampaian segala informasi terkait dengan produk. Menurut (Durianto, 2004), Brand Awareness dapat ditempuh dengan beberapa cara sebagai berikut : 
1. Pesan yang disampaikan harus mudah diingat dan berbeda dibandingkan dengan lainnya serta harus ada hubungan antara merek dengan kategori produk.

2. Memakai slogan atau jingle lagu yang menarik sehingga membantu konsumen untuk meningkatkan merek

3. Jika produk mempunyai simbol, hendaknya simbol yang dipakai dapat dihubungkan dengan mereknya.

4. Perluasan nama merek dapat dipakai dengan menggunakan suatu isyarat sesuai kategori produk, merek atau keduanya Melakukan pengulangan untuk meningkatkan pengingatan karena membentuk ingatan lebih susah dibandingkan melakukan pengenalan.

\section{Metode Penelitian}

Pendekatan penelitian ini menggunakan metode kualitatif, dengan maksud untuk memahami dan menggali lebih dalam mengenai DBL Academy. Objek yang dibahas oleh penulis adalah DBL Academy yang merupakan salah satu bagian dari DBL Indonesia. Pembahasan kali ini lebih bertumpu bagaimana DBL Academy menerapkan Marketing mix dalam melakukan pembangunan merk mereka. Metode analisa yang digunakan adalah penulis adalah metode analisis dan metode deskriptif. Analisis deskriptif kualitatif adalah prosedur pengumpulan data deskriptif yang didapat dari hasil literasi dari buku maupun sumber lain yang sifatnya umum dan terbuka (Moleong, 2019).

Tujuan utama penelitian kualitatif deskritif adalah untuk menggambarkan dan juga mengungkapkan realita sosial maupun fenomena sosial (Pujileksono, 2015). Tujuan dari penelitian deskriptif kualitatif yang lain adalah untuk meringkas fenomena sosial untuk menggambarkan realita situasi yang sedang dibahas (Bungin, 2007). Data yang digunakan merupakan data sekunder, yang diperoleh dari studi literatur dan studi pustaka sebagai pendukung untuk menyelesaikan masalah (Malhotra, 2005)

\section{Hasil dan Pembahasan}

Penelitian ini dilakukan dengan tujuan dapat mengetahui manajemen pemasaran yang dilakukan oleh sekolah bola basket DBL Academy, yang bisa memberikan sumbangsih ilmu pengetahuan dan informasi tentang manajemen pemasaran DBL Academy dan bagi suatu sekolah bolabasket yang lain. Berikut adalah hasil penelitian tentang manajemen pemasaran sekolah bola basket DBL Academy yang telah dilakukan.

\section{Program DBL Academy}

Program di DBL academy dibagi menjadi 5 kategori yang didasarkan pada rentang usia. Segmentasi pasar perusahaan ini adalah anak-anak, akan tetapi value dari segmentasi ini ditujukan kepada orang tua yang menyekolahkan anak-anaknya di DBL academy. Berikut adalah pembagian kategori program DBL Academy.

- Prehoops : segmentasi umur 2-4 tahun

Pada tahap ini difokuskan untuk mengasah dasar motorik anak lewat permainan yang menyenangkan, serta membangun kebiasaan yang baik untuk bergerak aktif.

- Hoops Kids : segmentasi umur 5-6 tahun 
Pada tahap ini difokuskan untuk mengasah kemampuan anak dalam mengantur dirinya (self control), bersosialisasi terhadap teman-temannya, mengenali emosi, dan pengembangan motoric pada dirinya.

- Hoops : segmentasi umur 7-9 tahun

Pada tahap ini difokuskan untuk mengenali fundamental basket. Siswa akan diajarkan untuk menyelesaikan masalah, dan mengenali teamwork dari permainan bola basket

- Rookie : segmentasi umur 10-12 tahun

Pada tahap ini difokuskan untuk membangun fundamental basketball skill secara perlahan dan lebih luas dan melatih game sense dari basket. Mulai mempelajari dan mengenali peraturan permainan basket, strategi dan taktik dalam lapangan.

- Starter : segmentasi umur 13-15 tahun

Pada tahap ini difokuskan untuk memperkuat skill basket dan tipe tipe latian yang lebih detail. Tahap ini siswa juga diajarkan untuk menentukan target dan berkomitmen untuk mencapai target.

\section{Value Proposition DBL Academy}

Value proposition dapat diartikan sebagai nilai yang didapatkan dari konsumen sehingga konsumen lebih memilih kita dibandingkan orang lain (Hassan, 2012). Dengan kata lain, nilai apakah yang dapat diberikan DBL Academy terhadap konsumennya. Value proposition dari perusahaan ini ditujukan kepada orang tua siswa dengan harapan orang tua dapat merasakan perubahan kea rah yang lebih baik terhadap anak-anaknya dari segi mental, kesehatan, serta fisik.

Pada setiap siswa DBL Academy yang akan mendaftar, DBL Academy selalu memberikan trial latihan sebanyak empat kali dengan tujuan agar pelatih dapat mengertisejauh mana anak-anak tersebut dapat memahami materi basket. Setelah calon siswa melakukan trial latihan sebanyak empat kali, maka pihak DBL Academy akan melaporkan perkembangan anak tersebut kepada orang tua dalam bentuk laporan tertulis. Jika orang tua dari siswa tersebut setuju untuk melanjutkan pendaftaran pada pihak DBL Academy, maka DBL Academy akan melakukan tahap yang dinamakan placement test, tahap ini merupakan tahap yang terbagi lagi menjadi dua cara, yaitu yang pertama adalah measurement di mana siswa akan di uji secara fisik mulai dari tinggi badan, panjang tangan, tinggi loncatan, dan berat badan. Cara yang kedua adalah levelling yaitu siswa akan diuji tentang sejauh mana pemahaman basket yang dimiliki.

Setelah melewati kedua proses diatas, maka siswa menjadi siswa DBL Academy secara resmi dengan masa observasi selama 4 bulan. Setiap minggu dalam masa observasi tersebut, DBL Academy akan memberikan laporan kepada orang tua siswa lewat pertemuan secara tatap muka. Laporan tersebut menjelaskan tentang perkembangan anak tiap minggunya. Dalam masa observasi, total penerimaan laporan yang diberikan oleh DBL Academy sejumlah 16 laporan dengan satu kali laporan final untuk memberikan keterangan perkembangan anaknya mulai dari basketball skill, character building, dan nutria yang diperlukan.

Dengan detail dan standard SOP yang telah dimiliki oleh DBL Academy membuat perusahaan tersebut menjadikan sekolah non-akademik yang memiliki peminat yang cukup banyak. Di awal kemunculannya, siswa DBL Academy mencapai 300 siswa lebih (sudah 
termasuk semua kategori siswa). Target dari perusahaan ini adalah membentuk habbit dan attitude anak didiknya sehingga dapat mengalihkan energy yang biasanya digunakan untuk main gadget menjadikan sesuatu kegiatan yang positif. Tentunya value proposition dari perusahaan ini sangat matang karena sudah direncanakan sejak awal mula siswa akan didaftarkan sehingga orang tua tidak ragu untuk menyerahkan anak-anaknya ke dalam perusahaan ini yang tidak dimiliki oleh klub basket pada umumnya seperti CLS Knight, Pacific Caesar, Klub Sahabat Basketball, dll. DBL Academy juga mendekatkan dirinya kepada orang tua siswa sehingga secara tidak langsung akan menarik minat para orang tua untuk tetap menyekolahkan anak-anaknya di DBL Academy.

\section{Marketing Mix}

\section{Product}

Produk yang dimiliki oleh DBL Academy adalah sekolah basket untuk anak-anak hingga remaja. Sekolah basket yang dimiliki DBL Academy berbeda dari klub basket pdaa umunya. DBL Academy memiliki prosedur dan kurikulum yang menganut system basket internasional (World Basketball Australia). Sekolah ini tidak mengajarkan hanya sebatas latihan basket akan tetapi mencatat dari awal perkembangan anak, konsultasi nutrisi yang dibutuhkan, pemrograman latihan yang terstruktur yang dibina oleh pelatih professional. Product yang dimiliki juga tidak hanya yang disebutkan diatas, melainkan ada beberapa kompetisi internal antar kelas basket, shooting academy, mendatangkan pelatih basket dari klub nasional Indonesia dan masih banyak lagi. Tentunya dari produk yang ditawarkan, harapannya anak didiknya semakin terbuka wawasannya, dan pengembangan karakter dapat maksimal.

\section{Place}

Tempat yang dimiliki oleh DBL Academy memiliki 3 tempat yang tersebar di Surabaya dan Yogyakarta. Tempat yang berada di Surabaya di lokasi Pakuwon Mall JL. Mayjen Suwoyo dan Gedung Graha Pena di Jl Ahmad Yani 88 sedangkan lokasi yang di kota Yogyakarta berada di Jl. Magelang KM 5. No 165. Lokasi juga merupakan aspek penting dalam membangun kepercayaan pelanggan untuk tetap memilih kita. Standar lokasi yang digunakan sangat nyaman dengan standar NBA, ruangan ganti pria dan wanita yang terpisah dan dilengkapi dengan shower room, wifi di lobby yang nyaman dan luas.

\section{Price}

Harga yang dipatok pada saat awal berdirinya DBL Academy adalah 500 ribu per bulan. Tentunya harga ini menjadi sangat kompetitif jika dibandingkan dengan klub klub basket lainnya yang memiliki rentang harga 250-400 ribu per bulannya. Dengan standar internasional yang ditetapkan oleh DBL Academy dengan pelatihan dan lokasi yang mewah tentu harga 500 ribu per bulan menjadi daya tarik bagi para orang tua untuk menyekolahkan anak-anaknya di perusahaan ini.

\section{Promotion}

Promosi yang dilakukan DBL Academy cukup berbeda dari kluB basket lainnya. DBL Academy memilih untuk menggunakan banyak aktivitas untuk mengenalkan bahwa DBL 
Academy merupakan sekolah basket di Surabaya yang memiliki cara belajar yang berbeda dan juga sekolah basket yang memiliki kurikulum yang jelas dan berstandart internasional. DBL Academy mengklaim bahwa dialah satu-satunya sekolah basket pertama yang memiliki kurikulum dengan jelas dan terstruktur. Dari kesempatan ini, DBL Academy menerapkan "the law of leadership" yang artinya menjadi yang pertama dalam pangsa pasarnya.

DBL Academy dalam mendekati pasarnya tidak mengandalkan promosi via media cetak atau media online saja, melainkan memilih untuk langsung bertatap muka dengan pasarnya. Tujuannya adalah DBL Academy mampu mengambil perhatian dan minat orang tua siswa untuk mendaftarkan anak mereka di DBL Academy. Adapun langkah yang diterapkan adalah melakukan Roadshow Basketball Clinic ke sekolah-sekolah untuk langsung bertatapan dengan siswa siswa sekaligus melakukan Parents Gathering untuk menarik perhatian orang tua siswanya. Setelah roadshow dilakukan maka diadakan evaluasi seberapa banyak orang tua yang mendaftarkan anaknya ke DBL Academy, apabila target pendaftaran belum tercapai maka mereka harus mengganti dan mengevaluasi acara roadshow mereka mengapa sampai kurangnya jumlah pendaftar.

Roadshow Basketball Clinic ini menjadi poin komunikasi pasar yang sangat penting bagi DBL Academy, karena dari acara inilah DBL Academy memiliki peluang untuk langsung terjun ke pasar, bertatap muka dengan calon konsumennya dan mendapatkan kesempatan untuk langsung menarik perhatian konsumen. Apabila kesempatan ini disiasiakan, maka tentunya DBL Academy tidak memiliki peluang untuk bersaing dengan klub basket pada umumnya. Roadshow yang dilakukan memakan biaya yang tidak cukup murah dan oleh karena itu, target dari acara ini adalah seberapa banyak jumlah konsumen yang mendaftar pada DBL Academy.
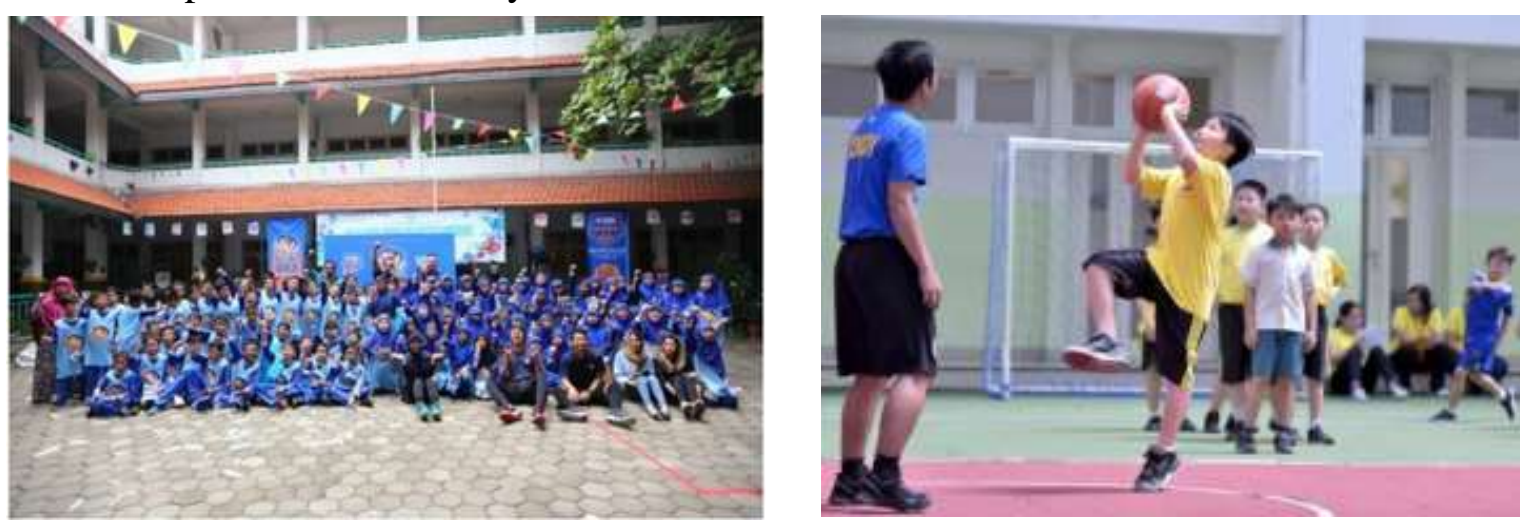

Gambar 3. Kegiatan Roadshow Basketball Clinic yang dilakukan DBL Academy di sekolah

Selain melakukan acara Roadshow, media instagram digunakan oleh DBL Academy sebagai wadah untuk memberikan pengumuman, promo menarik, serta acara atau event yang akan dilakukan dengan kolaborasi dari pihak lain. DBL Academy jarang mempromosikan dirinya di koran atau majalah karena dinilai kurang efektif dalam menarik pangsa pasarnya. Apalgi di era modern ini, sebuanya berbasis online dan tentunya instagram merupakan media yang sangat terkenal di belakangan ini. Instagram digunakan oleh DBL Academy untuk mempromosikan acara-acaranya seperti Mini Camp, Shoting Camp, Basketball Clinic, Internal Competitions, dan Kids Competitions. Media instagram digunakan secara maksimal oleh DBL Academy dengan selalu mengukur berapa jumlah pengunjung tiap harinya, jumlah 
follower dan tentunya menggunakan eksistensi instagram dengan menampilkan warna yang khas dari DBL Academy yaitu biru dan kuning. Dengan demikian, profile dari DBL Academy dapat menarik perhatian kalangan anak-anak hingga remaja dan eyecatching bagi orang tua untuk melihat acara-acara yang diselenggarakan oleh DBL Academy.

Selain menggunakan media instagram, DBL Academy mengharapkan adanya kekuatan dari "World of Mouth" para orang tua siswanya. Dengan berbagai acara dan penjelasan yang telah disampaikan oleh pihak DBL, diharapkan para orang tua dapat menyebarkan informasi yang dimiliki kepada orang tua siswa lainnya karena DBL menganggap bahwa orang tua siswa memiliki jaringan yang kuat terutama di media Whatsapp.

\section{People}

Sumber daya manusia sangat menentukan untuk kemajuan dan perkembangan dari perusahaan itu sendiri. Percuma saja apabila promosi, kegiatan, dan acara yang disampaikan begitu mewah tetapi pada saat masuk ke dalam perusahaan, konsumen tidak mendapatkan value yang baik. Oleh sebab itu, DBL Academy memperkerjakan orang-orang yang ahli di bidangnya dan memiliki jam terbang yang luas. Sebagai contoh ada Dimaz Muharri yang merupakan mantan pemain basket profesional dari klub CLS Knight Surabaya yang juga merupakan mantan punggawa tim nasional basket Indonesia. Erwin Triono juga muncul menjadi salah satu nama yang mencolok oleh karena pengalamannya melatih tim junior seperti PON Jawa Timur. Andrew Vlahov yang merupakan mantan pelatih salah satu klub profesional di Australia melengkapi daftar tim kepelatihan DBL Academy

Dilihat dari pengalaman serta keahliannya dalam bidang basket, DBL Academy menjamin konsumennya dengan pelatihan yang memiliki profesionalitas yang tinggi dalam bidang basket. Dengan demikian harapannya orang tua dapat meraskaan perkembangan anaknya setelah latihan di DBL Academy. Selain tiga pelatih diatas, SDM di DBL Academy memiliki coaching staff sebanyak 20 orang dengan latar belakang pelatih basket di berbagai sekolah di Indonesia.

\section{Process}

Proses di konsep ini mencakup bagaimana cara perusahaan melayani permintaan tiap konsumennya, mulai dari konsumen memesan hingga akhirnya mereka mendapatkan apa yang mereka inginkan. DBL Academy tentunya memiliki proses yang cukup detail dan terperinci jika dibandingkan klub basket lainnya. Proses untuk menjadi siswa DBL Academy juga sangat detail seperti yang sudah dijelaskan diatas sehingga orang tua siswa harapnnya mendapatkan laporan awal dan laporan akhir dari perkembangan dan pertumbuhan anaknya. Klub-klub basket lainnya tidak memiliki program untuk tiap usia, tetapi di DBL Academy memiliki program yang terstruktur untuk tiap kategori usia sehingga perkembangan lebih maksimal di usianya. Selain itu, proses di DBL Academy sendiri seperti Character Building untuk membangun soft skill anak dan jiwa sosial anak, Nutrition Class untuk mengatur pola makan siswa siswanya supaya dapat bertumbuh dengan baik, Exclusive Training yang mendatangkan pelatih dari Klub Nasional di Indonesia, Internal Competition yaitu pertandingan antar kelas di DBL Academy, DBL Academy Selection yaitu seleksi siswa siswa untuk dapat berangkat ke luar negeri dan bertanding dengan siswa luar negeri, dan 
masih banyak lagi. Acara-acara yang ditawarkan sangat menarik, tidak hanya berlatih basket melainkan disuguhi dengan berbagai acara yang menarik.

\section{Physical Evidence}

Physical evidence adalah bukti fisik yang dapat berwujud dalam bentuk logo, brosur, souvenir, akses untuk menghubungi customer service, seragam karyawan, event, dan website resmi. Physical evidence juga dapat menjelaskan bagaimana penataan bangunan dari suatu perusahaan dari segi interior, penataan lampu, deisgn ruangan ruangan yang menarik dan nyaman yang dapat mempengaruhi mood pengunjungnya.

Dalam konsep ini, DBL Academy menjunjung tingkat internasional yang diterapkan di semua sekotr mulai dari ruangan lobby, lapangan basket, kamar mandi, ruang ganti, kurikulum, media online dan memiliki website resmi. Di dalam website resmi kita juga dapat dengan bebas untuk melihat informasi yang berkaitan termasuk fasilitas, program, gallery, lokasi, store dan coaching staff di perusahaan tersebut.

\section{How Good is the Brand?}

Jika melihat paparan dan penjelasan tentang tujuh konsep marketing yang dilakukan DBL Academy secara tidak langsung memperkuat brand dari DBL Academy. Dari awal mula, DBL Academy dengan hati-hati untuk membangun merk ini agar persepsi pertama yang diingat oleh masyarakat adalah positif. DBL Academy berusaha untuk membangun sekolah non-akademik ini menjadi sesuatu yang mempunyai nilai yang tinggi dimata konsumennya. Mengingat bahwa di Indonesia, olahraga basket kurang disupport dan sedikit peminatnya tidak seperti di negara lain. Oleh sebab itu, DBL Academy mengusung kurikulum berbasis internasional yang tidak hanya memberikan pelatihan basket tetapi perkembangan dari anak itu sendiri dan dilampirkan dalam sebuah laporan sehingga para orang tua dapat memonitor pertumbuhan dan perkembangan anak-anaknya. Kotler dan Keller (2007), mendefinisikan ekuitas merek sebagai nilai tambah yang diberikan kepada produk dan jasa. Nilai ini bisa dicerminkan dalam bentuk cara seorang konsumen dalam berpikir, merasa, dan bertindak terhadap merek, harga, pangsa pasar, dan profitabilitas yang dimiliki perusahaan. Tentunya dari berbagai kategori pelatihan yang diberikan oleh DBL Academy mampu menarik pra orang tua untuk lebih memilih DBL Academy sebagai sekolah basket untuk anak-anaknya dibandingkan klub basket pada umunya yang hanya memberikan latihan basket saja.

DBL Academy juga merupakan klub basket pertama yang memiliki kurikulum berstandar internasional di Indonesia. Hal ini juga menjadi kesempatan yang besar bagi DBL untuk lebih mengembangkan program-program karena masih minimnya pesaing yang tidak mampu menandingi DBL Academy. Pertama kali dibuka, jumlah siswa yang dididik oleh DBL Academy adalah sebanyak 316 siswa yang terdiri dari 3 kelas yaitu hoops, rookie, dan kelas palng tinggi yaitu starter.

Akan tetapi, masalah yang terjadi di belakangan ini adalah turunnya konsumen DBL Academy menjadi kurang lebih 150 siswa karena biaya pendaftaran yang langsung naik 100\% dari harga 500 ribu per bulan menjadi 1 juta per bulan. Konsumen DBL Academy langsung menurun hingga 50\% karena kenaikan biaya tersebut. Hal ini berarti bahwa orang tua khusunya konsumen dari DBL merasa bahwa nilai 1 juta per bulan tidak sebanding 
dengan value yang diterima. Apabila dikulik lebih dalam sebenarnya alsan DBL Academyy menaikkan biaya ini karena ingin meningkatkan kualitas dari sarana dan fasilitas yag akan didapatkan oleh murid itu sendiri, namun respon dari orang tua murid ternyata tidak sesuai dengan ekspetasinya. Alhasil, orang tua lebih memilih untuk memasukkan anak-anaknya di klub basket pada umumnya seperti CLS Knight, Pacific Caesar yang sejatinya juga memiliki lapangan basket berstandar internasional. Sebenarnya masalah seperti ini dapat diatasi dengan melakukan edukasi terlebih dahulu kepada orang tua siswa mengenai masnfaatnya, dan juga alangkah lebih bak apabila kenaikkan tarif dikenakan secara bertingkat tidak langsung melakukan kenaikan $100 \%$ yang berdampak pada munculnya stigma negatif orang tua murid terhadap DBL Academy.

Dari kesalahan yang dilakukan, menurut hasil pengamatan kami, DBL Academy juga mendatangkan psikolog profesional untuk membimbing perkembangan siswa DBL dengan tujuan utama agar perubahan dan perkembangan anak lebih dirasakan oleh orang tua lewat perubahan sikap emosional anak ke arah yang lebih positif. Dan menurut kami, memberikan harga diskon yang sebenarnya juga sudah terlaksana juga memberikan dampak positif untuk dapat menaikkan konsumen DBL Academy. Diskon ini diberikan sebesar 30\% apabila orang tua siswa mengajak temannya untuk mendaftarkan anak nya di DBL Academy.

\section{DBL Academy vs Others}

DBL Academy bukan satu-satunya tempat sekolah basket, banyak persaingan yang terjadidi dunia basket terutama di sekolah basket. Beberapa kompetitor terdekatnya berada di Surabaya seperti CLS Knight dan Pacific Caesar. CLS dan PC ini adalah dua klub besar di Indonesia yang saat ini berkompetisi di liga basket tertinggi di Indonesia yaitu Indonesia Basketball League (IBL). CLS dan PC juga memiliki akademi basket seperti layaknya DBL Academy, bahkan usianya jauh diatas DBL Academy, keduanya sudah berumur puluhan tahun dan sudah menciptakan ratusan pebasket yang tersebar diseluruh Indonesia. Fokus dari CLS dan PC sebenarnya adalah pembibitan potensi basket untuk meneruskan klub mereka sehingga terbentuk regenrasi tim untuk menekan biaya pembelian pemain yang cukup tinggi. Namun apa yang berbeda dari DBL Academy, sehingga DBL Academy dapat sukses melawan CLS dan PC secara jumlah anggota ? Jawabannya adalah fundamental dan latar belakang didirikannya DBL Academy sendiri. DBL Academy menurut penulis lebih memiliki power karena memiliki massa yang banyak, dengan modal marketing mouth-tomouth pun mereka bisa secara digdaya melawan kekuatan CLS dan PC karena memiliki nama brand yang kuat dan melekat di kepala anak muda hingga orang dewasa. Selain itu keunggulan dari DBL Academy dibandingkan CLS dan PC adalah maslaah kurikulum yang tertulis dan konkrit berbeda dengan CLS dan PC yang cenderung mengandalkan satu pelatih dan kadang pelatih tidak mempedulikan ketika ada peserta yang membutuhkan bimbingan lebih untuk dapat memunculkan potensinya, karena CLS dan PC menerapkan sistem pukul rata - sama rata yang artinya tidak mempedulikan apa hasil dari yang diajarkan, yang penting saya sudah ajarkan, tunjukkan hasilnya. Berbeda dengan DBL Academy yang mengikuti proses perkembangan pesertanya sehingga kelemahan dan potensi masing-masing peserta dapat digali dan dikembangkan dengan maksimal. SEcara fasilitas, PC dan CLS memiliki fasilitas yang hampir sama dengan DBL Academy hanya saja DBL Academy lebih modern sehingga terlihat lebih bagus padahal lapangan CLS dan PC juga memiliki standar 
internasional karena digunakan untuk kompetisi IBL. Lebih jauh dari itu, teknik marketing yang digunakan DBL Academy lebih kuat karena langsung menyasar ke sekolah-sekolah sehingga lebih dikenal oleh masyarakat. KEunggulan DBL Academy lainnya adalah terkait koneksi dengan sekolah-sekolah yang ada di JAwa Timur khususnya karena mereka memiliki kompetisi DBL dan JRBL yang memiliki power yang sangat kuat sehingga celah tersebut dimanfaatkan untuk mengibarkan bendera DBL Academy.

\section{Kesimpulan}

Stengths :

- DBL Academy merupakan sekolah basket terbaik saat ini yang tidak hanya mengembangkan hardskill bermain basket namun mengembangkan softskill dari murid-muridnya

- Memiliki berbagai kelompok umur sehingga dapat memberikan materi sesuai dengan kemampuan murid

Weakness :

- Biaya yang tinggi menyebabkan pangsa pasar dari DBL Academy menyempit hnya untuk kalangan menengah keatas.

- Minimnya pengetahuan orang tua dari anak terkait pentingnya pengembangan skill basket sejak dini

\section{Opportunities :}

- Tingkat antusiasme basket di Kota Surabaya sangat tinggi, maka letak DBL Academy di Kota Surabaya sudah tepat

- Strategi pemasaran secara online masih terbuka lebar, dapat dimanfaatkan sedemikian rupa agar lebih masif perkenalan dirinya.

Threaths :

- Munculnya kompetitor akademi basket serupa yang menawarkan pelatihan basket dengan biaya yang lebih ringan

Dari analisis SWOT diatas sebenarnya peluang DBL Academy untuk menjadi yang terbesar sangat terbuka lebar, apalagi didukung dengan maraknya pemasaran menggunakan media online. Pusat DBL Academy yang ada di Surabaya juga menjadi peluang emas didepan mata karena Kota Surabaya merupakan salah satu kota basket, yang merupakan kota pertama diadakannya kompetisi DBL (Antar SMA) yang bisa menjadi pemacu motivasi anak usia dini untuk mengikuti jejak senior-seniornya untuk menjadi pemain DBL. DBL Academy seharusnya lebih menyasar branding kepada orang tua karena sejatinya yang mengeluarkan biaya dan mengambil keputusan untuk bergabung dengan DBL Academy adalah orang tua murid.

Dari tujuh konsep marketing yang telah dibangun oleh DBL Academy dapat disimpulkan bahwa DBL Academy mengambil strategi komunikasi pemasaran berupa mengambil kesadaran konsumennya dengan menjalankan evaluasi acara dengan jumlah pendaftar dari Roadshow yang dilakukan ke sekolah-sekolah, mengevaluasi jumlah 
pengunjung laman instagram dengan yang mendaftar via instagram dan websitenya dan juga mempelajari karakter konsumen khususnya orang tua siswa agar kekuatan word of mouth dapat berjalan dengan cepat.

Cara yang dilakukan untuk membangun kepuasan orangtua siswa adalah dengan hasil pembentukan karakter yang dilakukan oleh DBL Academy seperti karakter leadership, responsibility, warm, honest, care, dan role model serta membentuk kemampuan anak-anak dalam bermain basket dan berkompetisi sejak dini. 


\section{Bibliografi}

Agus, H. (2012). Komunikasi pemasaran. Jakarta: Erlangga.

Anthony E. Henry. (2011). Understanding Strategic Management, second edition. (US). Oxford University Press, Inc., New York.

Braet, J. (2007). The practice of new products and new business. Acco.

Bungin, B. (2007). Analisis data penelitian kualitatif.

Cristea, A. (2014). Positioning Strategies for Obtaining and Sustaining Competitive Advantage. International Journal of Economic Practices and Theories, 4(5), 894-902.

Durianto, D. (2004). Brand Equity Ten Strategi Memimpin Pasar. Gramedia Pustaka Utama.

Gould, R. (2012). Creating the strategy: Winning and keeping customers in B2B markets. Kogan Page Publishers.

Hassan, A. (2012). The value proposition concept in marketing: How customers perceive the value delivered by firms-A study of customer perspectives on supermarkets in Southampton in the United Kingdom. International Journal of Marketing Studies, 4(3), 68.

Hisrich, R. D. (2015). International entrepreneurship: starting, developing, and managing a global venture. Sage Publications.

Korkmaz, S., \& Messner, J. I. (2008). Competitive positioning and continuity of construction firms in international markets. Journal of Management in Engineering, 24(4), 207-216.

Kotler, P. and G. A. (2016). Principles of Marketing sixteenth edition. Pearson Education Limited.

Kotler, P., \& Keller, K. L. (2005). Manajemen Pemasaran, Jakarta: PT. Indeks Kelompok Gramedia.

Kotler, P., \& Keller, K. L. (2009). Manajemen Pemasaran, Edisi 13. Jakarta: Erlangga, 14.

Moleong, L. J. (2019). Metodologi penelitian kualitatif.

Pujileksono, S. (2015). Metode penelitian komunikasi kualitatif. Malang: Intrans Publishing. 